\title{
WAR AND CAPITAL PUNISHMENT
}

\author{
VICTORIA SCHNEIDER \\ Inter-University Consortium for Political and Social Research \\ University of Michigan \\ Ann Arbor, Michigan 48109 \\ JoHn ORTIZ SMYKLA \\ Department of Criminal Justice \\ The University of Alabama \\ Tuscaloosa, Alabama 35487-0320
}

\begin{abstract}
This article examines the relationship between war and capital punishment. Based on Executions in the United States, 1608-1987: The Espy File (Espy and Smykla, 1987), a new, comprehensive computer-readable data collection on the history of capital punishment, changes in execution rates were measured across World Wars 1 and II and the Korean War with a before-, during-, and afterdesign. After review of several theoretical reasons to suspect that executions might continue at the same level or even increase during and after war periods compared with prewar periods, it was found that the number of executions dropped during and after World Wars I and II and the Korean War compared to prewar periods of equal length. Explanations related to changes in the number of homicides or in public opinion are discounted. It is suggested that the changes are, in part, functions of the influence of women and the elderly during large-scale mobilization and of war-time parole, which required military service in lieu of incarceration and execution.
\end{abstract}

\section{INTRODUCTION}

This article examines the relationship between war and capital punishment. Specifically, it addresses the question of whether participation of the United States in a war affected the level of executions during and after war periods. There are several compelling theoretical reasons to suspect that executions might continue at the same level or even in- crease during and after wars compared with prewar periods. Perhaps the most powerful explanation is found in social learning theory (Bandura, 1973). Social learning or "modeling" suggests that acts of violence provide a model, which increases the likelihood of imitative violence. Furthermore, aggressive models are most influential when they are rewarded. It seemed plausible that official violence like war could provide a model for the 
ongoing exercise of social control through capital punishment, because capital punishment, like war, carries the full authority and prestige of the state with rewards for the killing and the killers.

The thesis that war fosters violence has a long history in public discussions and academic research. Erasmus, Sir Thomas More, Machiavelli, Sir Winston Churchill, and Clarence Darrow each speculated that war increases crime and lawlessness (Abbott, 1918; Darrow, 1922; Lowell, 1926). Research in England by Hanawalt (1979), in France by Durkheim (1951), and in the United States by Stein (1980) reported increases in violent crimes during times of civil and foreign wars. Durkheim argued that war reduces even the most cultivated society to a moral condition of the lowest kind: "As a result, the mass becomes the supreme social factor; a rigid authoritarian discipline is imposed on all volitions" (Durkheim, 1951:117). In a study of the impact of World Wars I and II, the Korean War, and the Vietnam War on domestic cohesion in the United States, Stein (1980) concluded that domestic cohesion decreases as a function of increases in the level of wartime mobilization. He wrote, ". . . (w)artime mobilization serves to decrease the degree of domestic cohesion in the long run, despite the fact that threat tends to increase the affiliative tendencies of the members of the society" (1980:15). A body of other research studics, each with a different focus and hence somewhat difficult to draw together, is available on the impact of war and the crime it generates (see Archer and Gartner, 1984: chapter 4). None, however, focuses on the impact of war on crime control.

Another reason to suspect that executions in the United States might continue at the same level or even increase during war compared with prewar periods relates to the potentially criminogenic social changes brought on by wartime mobilization. These include, but are not limited to, disruption of families by conscription, long employment hours, the existence of special crime opportunities, and the creation of new types of crime by special wartime regulations such as rationing.

A third reason to suspect that executions in the United States might continue at the same level or increase during war is that national data collected since 1900 indicate that crime (primarily murder and rape) has continued to increase through war years (Archer and Gartner, 1984: Part III; Stein, 1980: chapter 5). At least in the United States, the removal of young men from the civilian population through conscription and enlistment, the tendency not to convict or imprison persons arrested during major wars, and reductions in police forces have not depressed the steady increase of crimes punishable by death.

\section{Methodology}

One reason a study of the impact of war on capital punishment has not been attempted previously is that historical execution data have not been available. Recently, through a project at The University of Alabama, a new, comprehensive computer-readable data collection on the history of capital punishment in the United States has become available (Espy and Smykla, 1987). Known as Executions in the United States, 1608-1987: The Espy File, the project was supported by the University of Alabama Law Center and the National Science Foundation. ${ }^{1}$ The datafile contains information on twenty-one variables for 14,570 confirmed executions from 1608 through 6 July $1987 .^{2}$

The study design involved comparison of the number of executions before, during, and after war. Execution data were taken from Executions in the United States, 1608-1987. For reasons of datafile completeness discussed elsewhere (Espy and Smykla, 1987), only World Wars I and II and the Korean War were analyzed. The period of the Vietnam War (3 May 1965 through 27 January 1973) was omitted because of the de facto halt to executions beginning in 1968 and the 1972 decision in Furman v. Georgia, when the United States Supreme Court struck down, on EighthAmendment grounds, state and federal capital-punishment laws that permitted wide discretion in the application of the death penalty.

The lengths (in months) of World Wars I and $\mathrm{Il}$ and the Korean War were used to determine both pre- and postwar periods. Because the postwar period of World War II 
(September 1945 through May 1949) and the prewar period of the Korean War (April 1947 through May 1950) overlapped by twenty-six months, it was decided to adopt a one-year pre-, during-, and postwar interval to examine the period of the Korean conflict. The wars and their pre- and post-periods are shown in Table 1.

\section{DISCUSSION}

Data from Executions in the United States, $1608-1987$ show a relationship between wars and executions in the United States in the twentieth century. The data in Table 2 show reductions in the number of executions $d u r$ - ing and after World Wars I and II and the Korean War when compared to prewar periods of equal length.

Figure 1 illustrates the number of executions per year for the first six decades of the twentieth century. The scattergram shows no major trend across the first half of the twentieth century to explain the decrease in executions during and after World Wars I and II and the Korean War. The number of executions per year at the end of the first half of the twentieth century (83) did not differ dramatically from the number in 1900 (99). Furthermore, these declines in executions did not continue beyond the postwar periods. Hence, it appears that no consistent pattern in the reduction of executions existed for the first half of the twentieth century.

TABLE 1

Prewar, War Years, and Postwar Periods for World Wars I and II and Korean WAR

\begin{tabular}{cccc}
\hline War & Prewar Period & War Years $^{a}$ & Postwar Period \\
\hline World War I & 5 September 1915-5 & 6 April 1917-11 & 12 November 1918- \\
& April 1917 & November 1918 & 12 June 1920 \\
& (19 months) & (19 months) & (19 months) \\
World War II & 7 March 1938-7 & 8 December 1941-2 & 3 September 1945-3 \\
& December 1941 & September 1945 & June 1949; \\
& (45 months) & (45 months) & (45 months) \\
Korean War War $^{b}$ & 30 June 1949-29 & 30 June 1950-29 & 28 July 1953-27 \\
& June 1950 & June 1951 & July 1954 \\
\hline
\end{tabular}

Notes: ${ }^{a}$ Source for war years is Arthur A. Stein, The Nation at War (Baltimore, MD: Johns Hopkins University Press, 1980).

${ }^{b}$ Because of problems of overlap with post-World War II (45 months) and pre-Korean War (38 months), a oneyear pre-, during-, and post-Korean war period was adopted.

TABLE 2

Number and Percent Change of Executions Before, During, and Aftir World WARS I AND II AND THE KOREAN WAR

\begin{tabular}{lccccccc}
\hline & Before & & \multicolumn{2}{c}{ During } & & \multicolumn{2}{c}{ After } \\
\cline { 2 - 4 } \multicolumn{1}{c}{ War } & Number & & Number & \% Change & & Number & \% Change \\
\hline World War I & 159 & & 140 & -12 & 115 & -18 \\
World War II $_{\text {Korean War }}{ }^{2}$ & 554 & & 499 & -10 & & 495 & -1 \\
\hline
\end{tabular}

${ }^{a}$ One-year before-, during-, and after-war intervals were used with the Korean War to avoid problems of overlap with the post-World War II and pre-Korean War periods. 


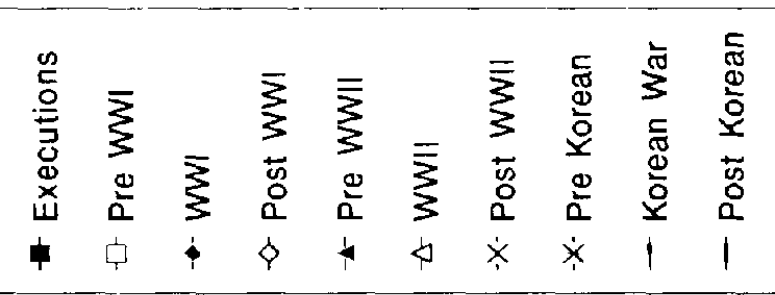
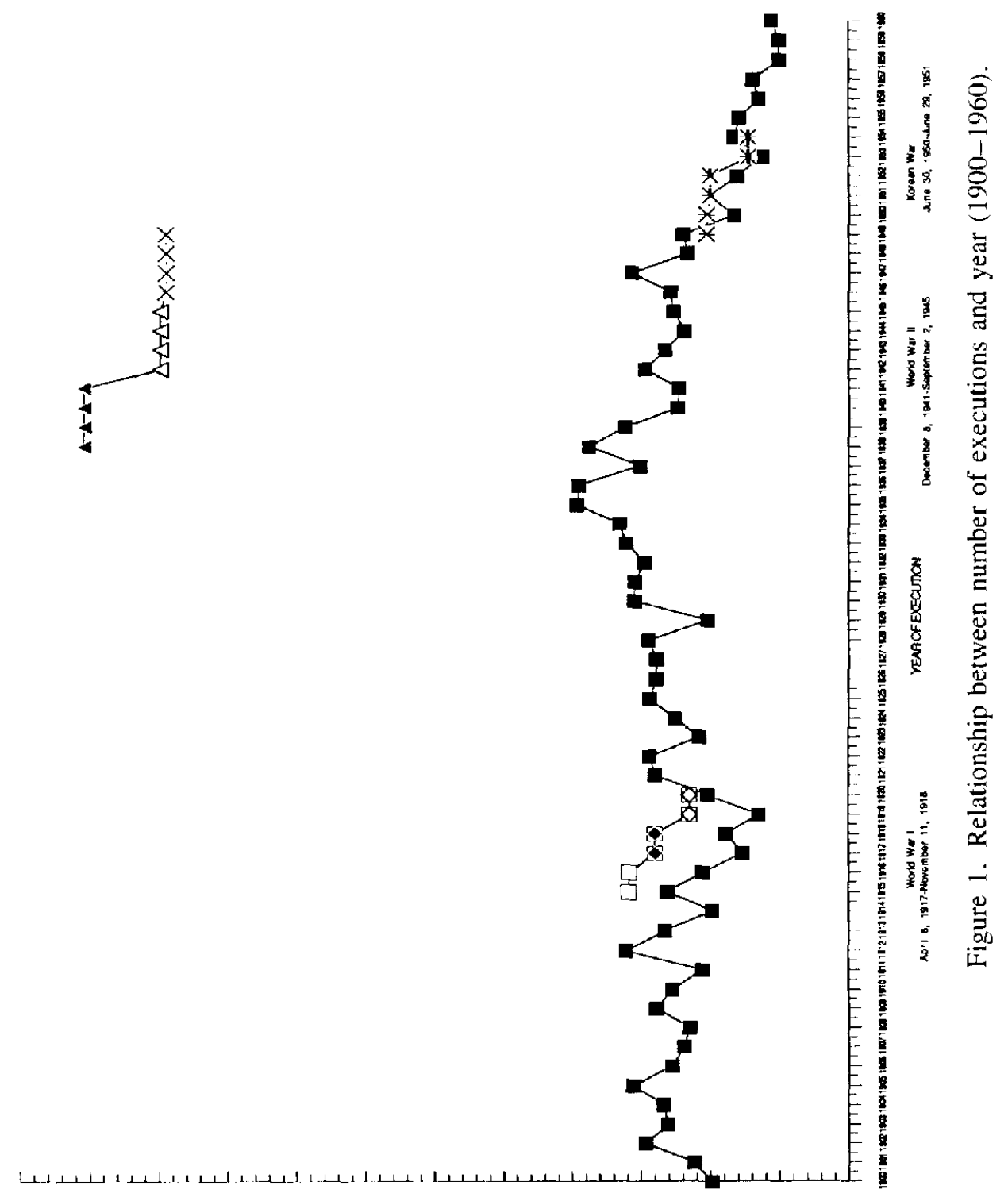

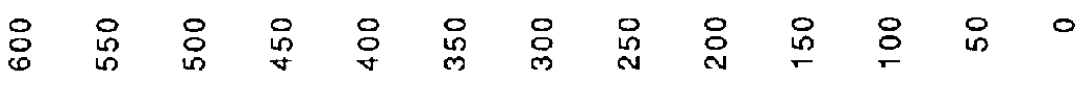


Two hypotheses that intuitively might explain the decreases in postwar executions shown in Table 2 are a decrease in the number of capital offenses during these time periods and shifts in public opinion. Table 3 provides data on the numbers and percent changes of capital offenses (murder and rape) before, during, and after World Wars I and II and the Korean War. The data for World War I indicate a slight increase ( 5.4 percent) in the number of homicides during the war compared to the pre-World War I period. The increase may be suggestive of the decrease in domestic cohesion hypothesized by Durkheim (1951) and Stein (1980). Executions, however, decreased twelve percent in the same time period (see Table 2). The pattern repeated itself in the period following World War I. Table 3 shows a slight increase $(+2$ percent) in the number of homicides following World War I but Table 2 shows a significant decrease $(-18$ percent) in the number of executions.

The relationship between capital offenses and executions before, during, and after World War II varied somewhat from the above, but the overall pattern is no less convincing. Capital offenses decreased by 8.7 percent during the forty-five months of World War II compared to the prewar period of forty-five months (see Table 3). Executions, however, decreased 10 percent (see Table 2). Following World War II homicide and rape increased by 8.2 percent but the number of executions declined only 1 percent.

The data for the Korean War show the same negative relationship, however slight at first. Capital offenses increased ( 1.7 percent) while executions decreased ( -3 percent) for the first 12 months of the Korean War compared to the one-year prewar period. One year after the close of the Korean War, however, capital offenses increased only slightly $(+0.7$ percent) while executions decreased dramatically ( -27 percent). Thus, contrary to this study's original hypothesis that executions might continue at the same level or even increase during and after wars compared with prewar periods, the data show that the number of executions dropped while the number of homicides generally increased during and after World Wars I and II and the Korean War compared to prewar periods of equal length.

The other hypothesis concerned the influence of public opinion on executions. The most comprehensive analysis so far of American death-penalty opinion is Bohm (in press). Bohm examined the fifty-year record of American death-penalty opinion, beginning with the first Gallup Poll survey that asked questions about the death penalty in 1936. In spite of the nine-percent increase in support and a seventeen-percent decrease in opposition to the death penalty across twenty-one polls from 1936 through 1986 (61 to 70 percent and 39 to 22 percent, respectively, Bohm, in press, 4), executions over the same fiftyyear period declined. A negative relationship between public opinion and executions is also supported by the finding that most countries that have abolished the death penalty have done so despite relatively strong public support for retention (Zimring and Hawkins, 1986).

Although no Gallup surveys of American death-penalty opinion were conducted during precisely the same periods examined in this study, the Gallup surveys of 2-7 December 1936 and 1-6 December 1937 cover time spans close to the prewar period of World War Il (7 March 1938 through 7 December 1941). In those surveys, 61 percent of the respondents answered "yes" they did "believe in the death penalty for murder." The next Gallup survey measuring American death-penalty opinion was conducted 1-5 November 1953. Seventy percent of the respondents favored capital punishment. If a nonlinear increase from 61 percent to 70 percent for the years 1937-1953 is assumed, a negative relationship between support for capital punishment and the number of executions emerges.

We believe that there are at least three potentially valid explanations for the relationship between war and capital punishment found in this study. The first combines the collective conscience of Durkheim with the psychoanalytic theory of Freud (1959). We suggest that during peacetime agents of social control generally view capital punishment as an act of symbolic unity for the collective conscience. During wartime, however, 


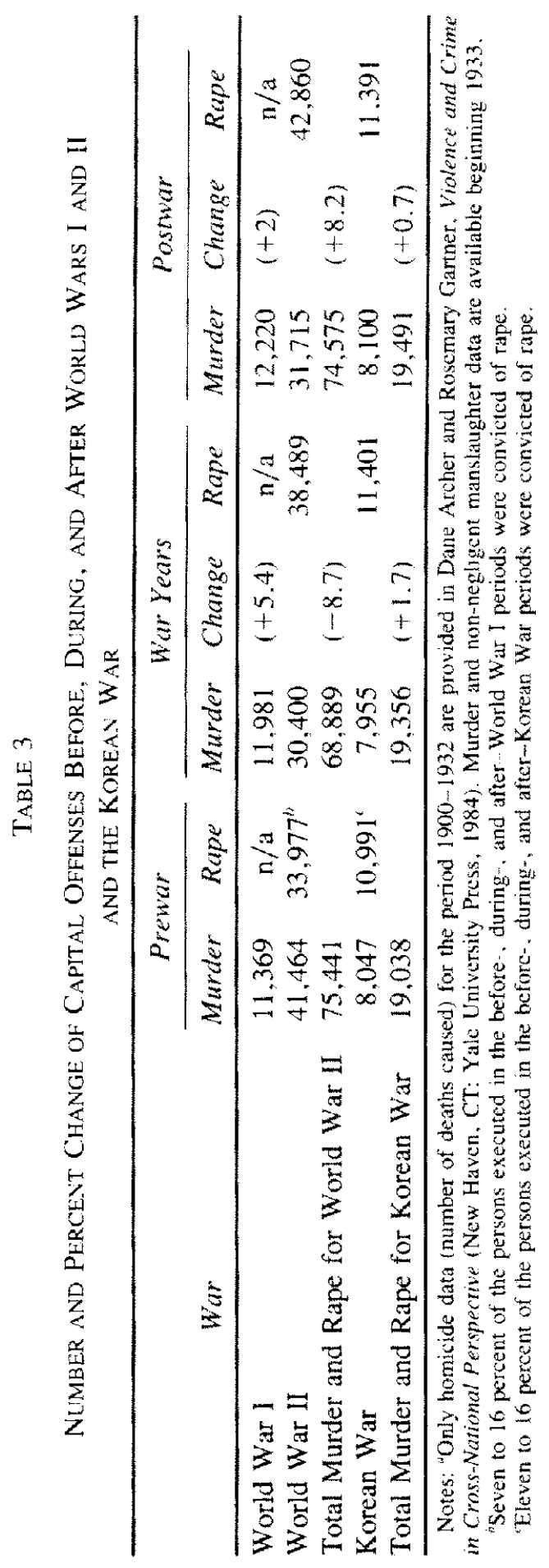


the symbols of unity are transferred to other levels of aggression and control. The focus is on killing the enemy and on victory instead of on executions. This hypothesis does not go so far as to assume total national unity during war. On the contrary, research in the United States by Stein (1980) has demonstrated that domestic cohesion decreases during war. Increased domestic cohesion may, however, account for some part of the decrease in postwar executions.

A second explanation for the data in Table 2 involves the influence of women in times of large-scale mobilization. Exactly when that influence is first felt is not known, but it does occur. Research by Gluck (1987) and others on the role of women in the aircraft industry during World War II has demonstrated the social change. Similar changes could just as easily have taken place in jury selection. In times of large-scale mobilization the criminal justice system might have to draw on a different pool of jurors, who are less in favor of capital punishment. Bohm (in press) demonstrates that attitudes toward capital punishment vary with certain demographic characteristics. Women have always favored the death penalty less than men, and until 1960 , people fifty and over were less likely to favor the death penalty than people under thirty. Older pcople, along with women in general, may have changed the direction of the executions reported in Table 2 .

Third, historians and agency professionals have suggested that changes in the number of executions during and immediately after a war could be a function of war-time parole. During wars parole has been granted to thousands of persons who otherwise would have remained incarcerated. During the Civil War, Alabama prisoners were used in the fortifications in Mobile to produce war supplies for the Confederate army. During World War I, Illinois instituted industrial parole and put offenders to work in ammunition plants. And, during World War II, war-time parole was used across the United States to parole persons to work in defense plants (see Braly, 1977). Hence, it is possible that some portion of the change in the numbers of executions reported in Table 2 could be explained by the practice of the nation's courts, which required military service in lieu of incarceration and execution.

\section{CONCLUSION}

This analysis of the relationship between war and capital punishment indicated a drop in the number of executions during and after World Wars I and II and the Korean War when compared to prewar periods of equal length. Explanations relating to a corresponding drop in the number of capital offenses or in public opinion were discounted. It is suggested that the influence women and older persons had on U.S. society during war times may have affected executions. It is also suggested that wartime parole was a factor since the judicial system in United States required military service in lieu of incarceration and execution.

\section{ACKNOWLEDGEMENTS}

Authors' names appear in alphabetical order according to the tirst letter of their surnames. Equal effort was made by both authors in preparing this article.

\section{NOTES}

1. The creation of the computcr-readable data file was supported by grant number SES-8409725, awarded to the University of Alabama by the National Science Foundation. A subgrant berween the University of Alabama and the University of Michigan provided further work on the data file.

2. Executions in the United States, 1608-1987: The Epsy File is a Class I machine-readable data collection distributed through the Inter-University Consortium for Political and Social Research at the University of Michigan (ICPSR archival study number 8451 ). It consists of one datafilc $(14,570$ logical records), one machinereadable codebook file, and one printed codebook. The study furnishes data on executions performed in the United States under civil authority between 1608 and 6 July 1987. It includes a description of each individual executed and the circumstances surrounding the crime for which the person was convicted. Variables include: age, race, name, sex, and occupation of the uffender; place, jurisdiction, date, and method of execution; and the crime for which the offender was executed. The data were originally collected by M. Watt Espy. A grant from the National Scicnce Foundation supported computerization of the executions that Espy had confirmed as of 6 July 1987 . It should be noted that Espy continues to confirm executions and to enhance knowledge about prior 
executions. Data entry progressed through several stages, including a final reliability check of every piece of data by Espy with his own data ledgers. The complete dataset was then transferred to ICPSR, where further consistency checks were performed. All records were carefully examined to locate and correct any wild codes. This database is an accurate representation of the records in Espy's ledgers as they existed on 6 July 1987. Detailed information on Espy's methodology for confirming executions and data entry and reliability checks for computerization of the data are described at length in the codebook.

\section{REFERENCES}

Abbott, E. (1918). Crime and the war. J Crim Law 9:32 45 .

Archer. D., and Gartner. R. (1984). Violence and crime in cross-national perspective. New Haven, CT: Yale University Press.

Bandura, A. (1973). Aggression: A social learning analysis. Englewood Cliffs, NJ: Prentice-Hall.

Braly, M. (1977). False starts: Memoirs of San Quentin and other prisons. New York: Penguin Books.

Bohm, R. (in press). American death penalty opinion, 1936-1986: A critical examination of the Gallup polls. In The death penalty in America: Current research, ed. R. Bohm, Cincinnati, OH: Anderson.
Darrow, C. (1922). Crime: Its causes and treatment. New York: Crowell.

Durkheim, E. (1897, reprint 1951). Suicide. New York: Free Press.

Espy, W., and Smykla, J. O. (1987). Executions in the United States, 1608-1987: The Epsy file (codebook). Tuscaloosa, AL: John Ortiz Smykla (producer); Ann Arbor, MI: Inter-University Consortium for Political and Social Research (distributor).

Freud, S. (1959). Thoughts for the times on war and death (trans. J. Travière,). In Collected papers (Vol 4). New York: Basic Books.

Gluck, S. B. (1987). Rosie the riveter. Boston, MA: Twayne Publishers.

Hanawalt, B. A. (1979). Crime and conflict in English communities. Cambridge, MA: Harvard University Press.

Lowell, A. L. (1926). Public opinion in war and peace. Cambridge, MA: Harvard University Press.

Stein, A. (1980). The nation at war. Baltimore, MD: The Johns Hopkins University Press.

Zimring, F., and Hawkins, G. (1986). Capital punishment and the American agenda. New York: Cambridge University Press.

\section{CASES SITED}

Furman v. Georgia (1972) 408 U.S. 238 (1972). 